\title{
Two novel aflatoxin-producing Aspergillus species from Argentinean peanuts
}

Correspondence

Robert A. Samson samson@cbs.knaw.nl

\author{
María B. Pildain, ${ }^{1}$ Jens C. Frisvad, ${ }^{2}$ Graciela Vaamonde, ${ }^{1}$ Daniel Cabral, ${ }^{1}$ \\ Janos Varga ${ }^{3,4}$ and Robert A. Samson ${ }^{3}$ \\ ${ }^{1}$ Faculty of Ciencias Exactas y Naturales, Pab. II, Lab. 69, University of Buenos Aires, CP EHA1428, \\ Buenos Aires, Argentina \\ ${ }^{2}$ Center for Microbial Biotechnology, BioCentrum-DTU, Building 221, Technical University of \\ Denmark, DK-2800 Kgs. Lyngby, Denmark \\ ${ }^{3}$ CBS Fungal Biodiversity Centre, PO Box 85167, 3508 AD Utrecht, The Netherlands \\ ${ }^{4}$ Department of Microbiology, Faculty of Sciences, University of Szeged, PO Box 533, \\ H-6701 Szeged, Hungary
}

\begin{abstract}
Two novel species from Aspergillus section Flavi from different species of Arachis (peanuts) in Argentina are described as Aspergillus arachidicola sp. nov. and Aspergillus minisclerotigenes sp. nov. Their novel taxonomic status was determined using a polyphasic taxonomic approach with phenotypic (morphology and extrolite profiles) and molecular ( $\beta$-tubulin and calmodulin gene sequences) characters. A. minisclerotigenes resembles Aspergillus flavus and Aspergillus parvisclerotigenus in producing aflatoxins $\mathrm{B}_{1}$ and $\mathrm{B}_{2}$, cyclopiazonic acid, kojic acid and aspergillic acid, but in addition it produces aflatoxins $G_{1}$ and $G_{2}$, aflavarins, aflatrem, aflavinines, parasiticolides and paspaline. This species also includes several isolates previously assigned to $A$. flavus group II and three Australian soil isolates. A. arachidicola produces aflatoxins $\mathrm{B}_{1}, \mathrm{~B}_{2}, \mathrm{G}_{1}$ and $\mathrm{G}_{2}$, kojic acid, chrysogine and parasiticolide, and some strains produce aspergillic acid. The type strain of $A$. arachidicola is CBS $117610^{\top}=\mathrm{IBT} 25020^{\top}$ and that of $A$. minisclerotigenes is CBS $117635^{\top}=\mathrm{IBT} 27196^{\top}$. The Mycobank accession numbers for Aspergillus minisclerotigenes sp. nov. and Aspergillus arachidicola sp. nov. are respectively MB 505188 and MB 505189 (http://www.mycobank.org).
\end{abstract}

\section{INTRODUCTION}

Aflatoxins are the most potent natural carcinogens known (JECFA, 1997), affecting all vertebrate animal species, including humans. Four compounds are commonly produced in foods, aflatoxins $B_{1}, B_{2}, G_{1}$ and $G_{2}$, but other bio-transformed aflatoxins may occur, for example in milk, such as aflatoxins $M_{1}$ and $M_{2}$ (Cole \& Cox, 1981). These mycotoxins have been shown to be produced by Aspergillus flavus, A. parasiticus (Codner et al., 1963; Schroeder, 1966), A. nomius (Kurtzman et al., 1987), A. pseudotamarii (Ito et al., 2001), A. bombycis (Peterson et al., 2001), A. toxicarius (Murakami, 1971; Murakami et al., 1982; Frisvad et al., 2004) and A. parvisclerotigenus (Saito \& Tsurota,

Abbreviations: $\mathrm{Cl}$, consistency index; $\mathrm{MP}$, maximum-parsimony; $\mathrm{NJ}$, neighbour-joining; RI, retention index.

The GenBank/EMBL/DDBJ accession numbers for the $\beta$-tubulin and calmodulin gene sequences of the strains examined in this study are shown in Fig. 1 and Supplementary Fig. S1.

A neighbour-joining phylogenetic tree based on calmodulin gene sequences and colour versions of Figs 2 and 3 are available as supplementary material with the online version of this paper.
1993, Frisvad et al., 2004) in Aspergillus section Flavi, by A. ochraceoroseus (Frisvad et al., 1999, Klich et al., 2000) and A. rambellii (Frisvad et al., 2005) in Aspergillus section Ochraceorosei and in Aspergillus section Nidulantes or the ascomycete genus Emericella by Emericella astellata (Frisvad et al., 2004) and E. venezuelensis (Frisvad \& Samson, 2004a).

The most important aflatoxin producers from a public health point of view are members of Aspergillus section Flavi, in particular A. flavus and A. parasiticus. Originally, several isolates of $A$. parasiticus were misidentified as $A$. flavus [for example NRRL 2999, 3000 and 3145 (Hesseltine et al., 1966; Applegate \& Chipley, 1973); corrected to A. parasiticus by Hesseltine et al., 1970], and therefore G-type aflatoxins were connected with A. flavus. Like A. pseudotamarii and 'A. flavus' NRRL 3251, A. flavus has later been reported to produce only B-type aflatoxins (Dorner et al., 1984; Klich \& Pitt, 1985; Bennett \& Papa, 1988; Ito et al., 2001; Ehrlich et al., 2004; Frisvad et al., 2005), while A. parasiticus, A. toxicarius, A. nomius and A. bombycis can produce both B- and G-type aflatoxins (Ehrlich et al., 2004; Frisvad et al., 2005). There are many reports to indicate 
that certain A. flavus strains, microsclerotial strains, and strains listed as intermediate between A. flavus and A. parasiticus can also produce G-type aflatoxins (Codner et al., 1963; Hesseltine et al., 1970; Cotty \& Cardwell, 1999). Many aflatoxin B- and G-producing strains have been reported to produce small sclerotia, but they do not obviously belong to A parvisclerotigenus (Saito \& Tsurota, 1993; Cotty \& Cardwell, 1999; Bayman \& Cotty, 1993; Egel et al., 1994; Frisvad et al., 2005). Isolates in section Flavi producing small sclerotia apparently produce the same mixture of indoloditerpene alkaloids, whether they produce only B-type aflatoxins (NRRL 3251) or both B- and G-type aflatoxins [CBS 121.62 (=NRRL A-11612) and Nigerian and Indonesian strains] (Tanaka et al., 1989). There is phylogenetic evidence that Aspergillus flavus sensu lato may consist of several species (Geiser et al., 1998, 2000; Chang et al., 2006). However, this is difficult to evaluate, as most strains examined in those studies were generally not deposited in major culture collections. In order to find out whether such $\mathrm{B}+\mathrm{G}$-type aflatoxin producers belonged to one or more species, we surveyed various Arachis species in Argentina because such wild specimens of Arachis could be expected to harbour a more diverse mycobiota than domesticated peanuts (Arachis hypogaea), which have been examined in depth by many authors (e.g. Austwick \& Ayerst, 1963). Isolates representing A. flavus group II as defined by Geiser et al. $(1998,2000)$ and soil isolates from Australia kindly provided by J. I. Pitt (CSIRO, North Ryde, Australia) were also included in the analyses.

We have used a polyphasic taxonomic approach in order to determine the taxon delimitation (Frisvad \& Samson, 2004b; Varga et al., 2007; Houbraken et al., 2007, Samson et al., 2007a, b). For the phenotypic analyses, macro- and micromorphology, extrolite profiles and growth temperatures were studied. For the phylogenetic analyses, $\beta$-tubulin and calmodulin gene sequences were used.

\section{METHODS}

Isolates. The strains examined listed in Table 1 were cultures from the CBS (CBS Fungal Biodiversity Centre, Utrecht, Netherlands), NRRL (NCAUR Culture Collection, Peoria, IL, USA) or IBT (at BioCentrum-DTU, Kgs. Lyngby, Denmark) collections or they were freshly isolated from seeds and leaves of cultivated peanut (Arachis hypogaea L.) and leaves of autochthonous peanut species [Arachis villosa Benth., Arachis correntina (Burkart) Krapov. \& W. Gregory, Arachis glabrata Benth. and Arachis burkartii Handro] from Argentina. The Argentinean strains were chosen based on being representatives of known vegetative compatibility groups (VCGs) of A. flavus and from different hosts and agroecological zones within Argentina (Vaamonde et al., 1995; Novas \& Cabral, 2002; Pildain et al., 2003, 2004).

Morphology and extrolite profiles. For macromorphological observations, isolates were grown on Czapek yeast autolysate (CYA), malt extract agar (MEA), Czapek agar (CZA), yeast extract sucrose (YES) agar, oatmeal agar (OA) and creatine sucrose agar (CREA) (Samson et al., 2004). Aspergillus flavus and parasiticus agar (AFPA; Pitt et al., 1983) was used to determine the production of aflatoxins on agar medium. The strains were inoculated at three points and incubated at $25{ }^{\circ} \mathrm{C}$ in the dark for 7 days and/or at 37 and $42{ }^{\circ} \mathrm{C}$ on CYA. For micromorphological observations, microscope mounts were made in lactic acid from MEA colonies and a drop of alcohol was added to remove air bubbles and excess conidia. Extrolites were analysed by HPLC using alkylphenone retention indices and diode array UV-VIS detection according to Frisvad \& Thrane (1993), as modified by Smedsgaard (1997).

Genotypic analysis. The cultures used for molecular studies were grown in $2 \mathrm{ml}$ malt peptone (MP) broth, containing $10 \%(\mathrm{v} / \mathrm{v})$ malt extract (Brix 10) and $0.1 \%(\mathrm{w} / \mathrm{v})$ bacto peptone (Difco), in $15 \mathrm{ml}$ tubes. The cultures were incubated at $25{ }^{\circ} \mathrm{C}$ for 7 days in light/ darkness. DNA was extracted from the cells using the Masterpure yeast DNA purification kit (Epicentre Biotechnologies) according to the instructions of the manufacturer. A fragment of the $5^{\prime}$ portion of the $\beta$-tubulin gene was amplified using primers bt $2 \mathrm{a}$ and bt $2 \mathrm{~b}$ (Glass \& Donaldson, 1995), while a segment of the calmodulin gene was amplified using primers cmd5 and cmd6 as described by Hong et al. (2006). The amplified DNA fragments were purified using a QIAquick PCR purification kit (Qiagene). DNA sequences were determined using a BigDye Terminator v3.1 cycle sequencing kit (ABI) and an ABI 3100 DNA sequencer. Both strands of each fragment were sequenced.

DNA sequences were edited with the DNASTAR computer package and an alignment of the sequences was performed using the CLUSTAL $\mathrm{W}$ program (Thompson et al., 1994). The neighbour-joining (NJ) method was used for the phylogenetic analysis. For NJ analysis, the data were first analysed using the Tamura-Nei parameter distance calculation model with gamma-distributed substitution rates, which were then used to construct the NJ tree with MEGA version 3.1 (Kumar et al., 2004). To determine the support for each clade, a bootstrap analysis was performed with 1000 replications.

Phylogenetic analysis of sequence data was also performed using PAUP $^{*} 4.0 \mathrm{~b} 10$ (Swofford, 2000). Alignment gaps were treated as a fifth character state, uninformative characters were excluded and all characters were unordered and weighted equally. Maximum-parsimony (MP) analysis was performed for all datasets using the heuristic search option. To assess the robustness of the topology, 1000 bootstrap replicates were run by maximum-parsimony (Hillis \& Bull, 1993). Other measures including tree length, consistency index and retention index (CI and $\mathrm{RI}$, respectively) were also calculated. Sequences were deposited at GenBank under accession numbers listed in Fig. 1 and Supplementary Fig. S1 (available in IJSEM Online).

\section{RESULTS}

\section{Morphological analysis}

In our survey, six species from Aspergillus section Flavi were isolated from Argentinean wild peanut species: $A$. caelatus, A. flavus, A. tamarii and A. parasiticus and two taxa related to A. parvisclerotigenus and A. parasiticus. All Aspergillus isolates analysed by microscope examination exhibited conidial heads in shades from yellow-green to brown and had similar colony characteristics and growth rates on all media analysed in this study, and they all grew very fast at $37{ }^{\circ} \mathrm{C}$. These are typical morphological features associated with Aspergillus section Flavi (Raper \& Fennell, 1965). The strains from Argentinean peanuts were compared to ex type and authentic strains of species in Aspergillus section Flavi (see Table 1) and could be divided 
Table 1. Aspergillus isolates examined

\begin{tabular}{|c|c|c|}
\hline Isolate number & Source ${ }^{*}$ & Species name \\
\hline CBS $117610^{\mathrm{T}}=$ IBT $25020^{\mathrm{T}}$ & Arachis glabrata leaf; CO, Argentina & A. arachidicola \\
\hline CBS $117611=$ IBT 27185 & Arachis glabrata leaf; CO, Argentina & A. arachidicola \\
\hline CBS $117615=$ IBT 27178 & Arachis glabrata leaf; CO, Argentina & A. arachidicola \\
\hline CBS $117614=$ IBT 27183 & Arachis glabrata leaf; CO, Argentina & A. arachidicola \\
\hline IBT 27215 & Arachis glabrata leaf; CO, Argentina & A. arachidicola \\
\hline CBS $117187^{\mathrm{T}}=\mathrm{NRRL} 26010^{\mathrm{T}}$ & Frass in a silkworm rearing house; Japan & A. bombycis \\
\hline CBS 117616 & Arachis burkartii leaf; CO, Argentina & A. caelatus \\
\hline CBS $763.97^{\mathrm{T}}=$ NRRL $25528^{\mathrm{T}}$ & Soil; USA & A. caelatus \\
\hline CBS $764.97=$ NRRL 25404 & Soil; USA & A. caelatus \\
\hline CBS $110.55^{\mathrm{T}}$ & Air contaminant; Brazil & A. fasciculatus \\
\hline CBS $484.65^{\mathrm{T}}$ & Air contaminant; Brazil & A. flavofurcatus \\
\hline CBS 117632 & Arachis hypogaea seed; FO, Argentina & A. flavus \\
\hline CBS 117624 & Arachis glabrata leaf; $\mathrm{CO}$, Argentina & A. flavus \\
\hline CBS $100927^{\mathrm{T}}$ & Cellophane; South Pacific Islands & A. flavus \\
\hline CBS 117733 & Hospital strain; Netherlands & A. flavus \\
\hline CBS 116.48 & Unknown source; Netherlands & A. flavus \\
\hline CBS 616.94 & Man, orbital tumour; Germany & A. flavus \\
\hline CBS $485.65^{\mathrm{T}}$ & Butter; Japan & A. flavus var. columnaris \\
\hline CBS 117731 & Dipodomys spectabilis cheek pouch; New Mexico, USA & A. flavus var. columnaris \\
\hline CBS $542.69^{\mathrm{T}}$ & Stratigraphic core sample; Japan & A. kambarensis \\
\hline CBS $151.66^{\mathrm{T}}$ & Dung of Lepus townsendii; USA & A. leporis \\
\hline CBS $117620=$ IBT 27198 & Arachis hypogaea seed; SA, Argentina & A. minisclerotigenes \\
\hline NRRL A-11611 = NRRL 6444 & Soil, peanut field, Nigeria & A. minisclerotigenes \\
\hline FRR 4086 & Freshly pulled peanuts, Kingaroy, Queensland, Australia & A. minisclerotigenes \\
\hline FRR 4937 & Soil, Australia & A. minisclerotigenes \\
\hline FRR 5309 & Soil, Australia & A. minisclerotigenes \\
\hline $1-22$ & Soil, peanut field, Australia & A. minisclerotigenes \\
\hline $4-2$ & Soil, peanut field, Australia & A. minisclerotigenes \\
\hline NPL TX12-10-2s & Soil, peanut field, Texas, USA & A. minisclerotigenes \\
\hline CBS $260.88^{\mathrm{T}}=\mathrm{NRRL} 13137^{\mathrm{T}}$ & Wheat; USA & A. nomius \\
\hline CBS $100925^{\mathrm{T}}$ & Unknown source; Japan & A. oryzae \\
\hline CBS 117638 & Arachis hypogaea seed; CO, Argentina & A. parasiticus \\
\hline CBS 117617 & Arachis villosa leaf; $\mathrm{CO}$, Argentina & A. parasiticus \\
\hline CBS 117618 & Arachis correntina leaf; CO, Argentina & A. parasiticus \\
\hline CBS $100926^{\mathrm{T}}$ & Pseudococcus calceolariae, sugar cane mealy bug; Hawaii, USA & A. parasiticus \\
\hline CBS $260.67^{\mathrm{T}}$ & Unknown source; Japan & A. parasiticus var. globosus \\
\hline CBS $121.62^{\mathrm{T}}$ & Arachis hypogaea; Nigeria & A. parvisclerotigenus \\
\hline CBS $766.97^{\mathrm{T}}=\mathrm{NRRL} 25517^{\mathrm{T}}$ & Soil; USA & A. pseudotamarii \\
\hline CBS 766.97 & Soil; USA & A. pseudotamarii \\
\hline CBS $100928^{\mathrm{T}}$ & Soy sauce; Japan & A. sojae \\
\hline CBS 100929 & Soy sauce; Japan & A. sojae \\
\hline CBS $501.65^{\mathrm{T}}$ & Cotton lintafelt, UK & A. subolivaceus \\
\hline CBS $104.13^{\mathrm{T}}$ & Activated carbon & A. tamarii \\
\hline
\end{tabular}


Table 1. cont.

\begin{tabular}{|lll|}
\hline Isolate number & & Source \\
\hline CBS 117626 & Arachis hypogaea seed; SA, Argentina & Species name \\
CBS $580.65^{\mathrm{T}}$ & Soil; USA & A. tamarii \\
CBS 119.51 & Japan & A. terricola var. americanus \\
CBS $120.51^{\mathrm{T}}$ & Culture contaminant & A. terricola var. americanus \\
CBS $822.72^{\mathrm{T}}$ & Arachis hypogaea; Uganda & A. thomii \\
& & A. toxicarius \\
\hline
\end{tabular}

*Peanut-producing provinces in Argentina: CD, Córdoba; CO, Corrientes; FO, Formosa; SA, Salta.

into two groups. One group of isolates (represented by CBS 117626) was similar to $A$. tamarii and was characterized by dark-brown conidia with conspicuously roughened to tuberculate thick walls and colonies with a dark-brown reverse on AFPA. The only species with such characteristics included A. tamarii, A. pseudotamarii and A. caelatus. The remaining strains had light to dark yellow-green conidia and less conspicuously roughened conidia. They also had a cadmium orange- or cream-coloured reverse on AFPA.

Isolates of $A$. flavus have been reported to produce two types of sclerotia, small (S) and large (L) (Cotty, 1989). In our study, we found 16 strains (represented by CBS 117620, CBS 117633-117635 and CBS 117639) with small sclerotia, which were similar to A. parvisclerotigenus CBS $121.62^{\mathrm{T}}$. One $A$. parasiticus isolate produced sclerotia of intermediate size (CBS 117618), while A. flavus IBT 27177, CBS 117622, CBS 117630 and CBS 117733 produced large sclerotia.

\section{DNA analysis}

For the molecular analysis, two regions of the genome were analysed, namely parts of the calmodulin and $\beta$-tubulin genes of the isolates. For the analysis of part of the $\beta$ tubulin gene, 510 characters were analysed. Among the 128 polymorphic sites, 74 were found to be phylogenetically informative. The $\mathrm{NJ}$ tree based on partial $\beta$-tubulin genes sequences is shown in Fig. 1. The topology of the tree is the same as one of the more than $10^{5} \mathrm{MP}$ trees constructed by the PAUP program (tree length, 173 steps; CI, 0.8844; RI, $0.9564)$.

The calmodulin dataset included 520 characters, with 80 parsimony informative characters. The topology of the NJ tree (Supplementary Fig. S1) was the same as one of the more than $10^{5}$ MP trees (length, 229; CI, 0.8603; RI, $0.9290)$.

Most of the sequenced Argentinean isolates fell into one of two main clades, represented by $A$. flavus and $A$. parasiticus. Isolate CBS 117616 was related to A. caelatus (Horn, 1997), which we could also confirm by its morphology. A. sojae, A. toxicarius and A. terricola var. americanus were found to belong to the A. parasiticus clade. Four isolates (CBS 117610-117612 and CBS 117615) from Arachis glabrata leaves formed a well-defined clade related to $A$. parasiticus on the trees based on $\beta$-tubulin and calmodulin data (Fig. 1 and Supplementary Fig. S1). However, these isolates have internal transcribed spacer (ITS) sequences identical to those of $A$. parasiticus (data not shown). Another six Argentinean isolates from Arachis hypogaea seeds formed a well-defined clade related to $A$. flavus and A. parvisclerotigenus on trees based on $\beta$-tubulin and calmodulin sequence data (Fig. 1 and Supplementary Fig. S1). These results are in agreement with our morphological and extrolite results. Furthermore, these Argentinean isolates belong to the same VCG as described by Pildain et al. $(2004,2005)$. This clade also includes four isolates assigned to A. flavus group II by Geiser et al. (1998, 2000) and three isolates collected from soils from Australia, all producing small sclerotia. Our calmodulin and $\beta$ tubulin sequence data indicate that $A$. oryzae, A.thomii, A. kambarensis, A. fasciculatus and A. subolivaceus are very closely related to A. flavus.

\section{Extrolites}

In our extrolite study of 34 strains from Argentinean peanuts, we found that the strains which were identified as A. flavus produced kojic acid $(100 \%)$, aspergillic acid $(100 \%)$, cyclopiazonic acid $(82 \%)$, aflatoxins $\mathrm{B}_{1}$ and $\mathrm{B}_{2}$ $(74 \%)$, oryzaechlorin $(44 \%)$ and flavimine $(94 \%)$ (Table 2). A single strain of A. tamarii from Argentinean peanuts produced kojic acid and oryzaechlorin. Four strains of $A$. parasiticus from Argentinean peanuts produced aflatoxins $B_{1}, B_{2}, G_{1}$ and $G_{2}$, aspergillic acid, kojic acid and parasiticolides, one strain (IBT 27180) produced oryzaechlorin, one strain (IBT 27194) produced paspaline and paspalinine and one strain (CBS 117618) produced aflavinines and other sclerotial metabolites.

Sixteen strains from Argentinean peanuts with small sclerotia produced aflatoxins $B_{1}, B_{2}, G_{1}$ and $G_{2}(100 \%)$, aflatrem ( $88 \%$ ), aflavarins (38\%), aflavinines (dihydroxyaflavinine, monohydroxyaflavinine, monohydroxyisoaflavinine and aflavinine) (100\%), aspergillic acid (100\%), cyclopiazonic acid (100\%), kojic acid (100\%), parasiticolides $(100 \%)$ and paspaline, paspalinine and emindole SB $(100 \%)$. This extrolite profile is very similar to that of $A$. parvisclerotigenus, but the Argentinean strains did not produce parasiticolides. Furthermore, A. parvisclerotigenus produced the compound A 30461 (oryzaechlorin). One of 


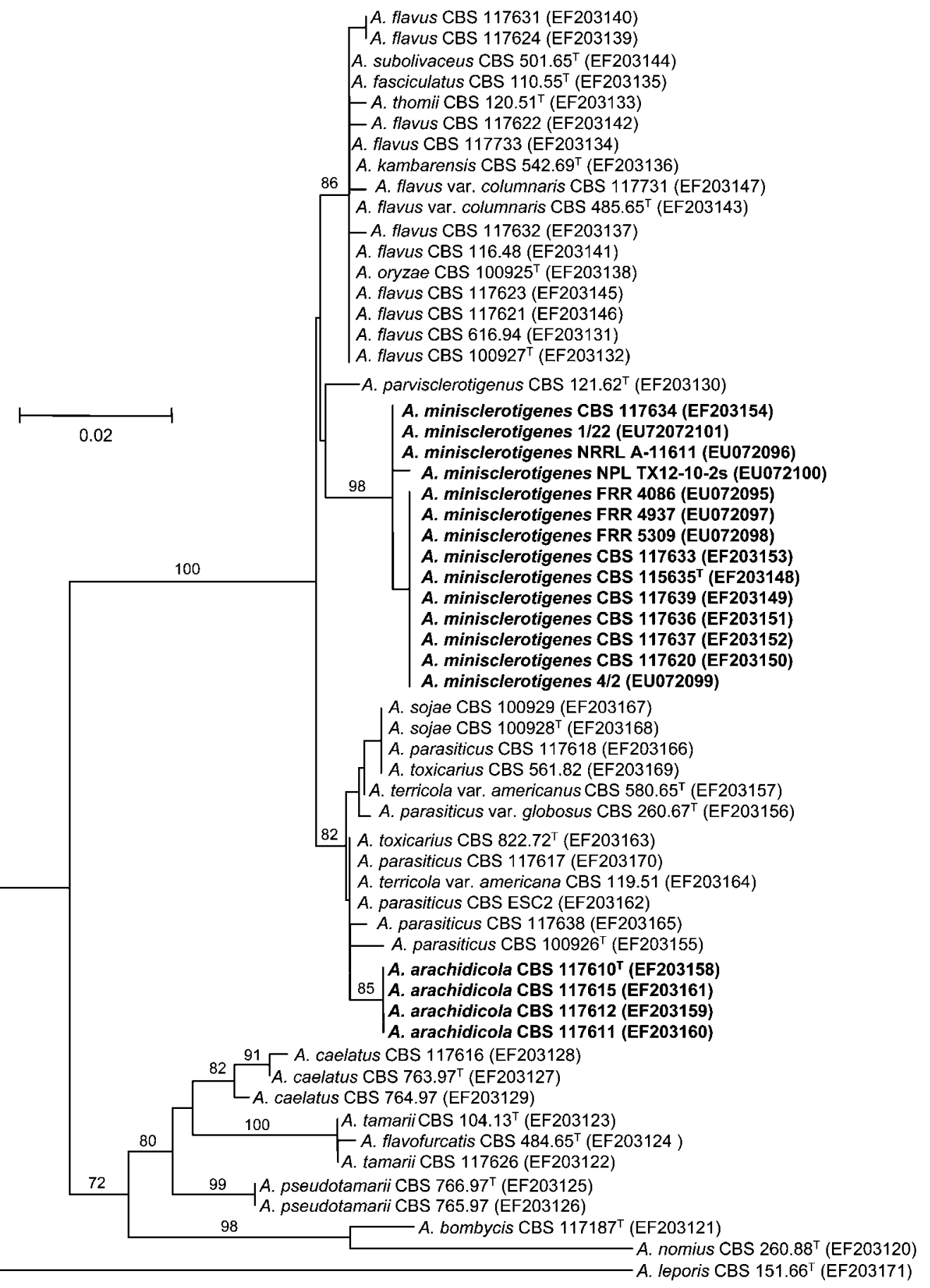

Fig. 1. Neighbour-joining tree based on $\beta$-tubulin sequence data of Aspergillus section Flavi. Numbers above branches are bootstrap values. Only values above $70 \%$ are indicated. Bar, 2 substitutions per 100 nucleotide positions.

the strains listed by Hesseltine et al. (1970), NRRL A-11611 (=NRRL 6444), also produced aflatoxin $B_{1}, B_{2}, G_{1}$ and $G_{2}$, aflatrem, aflavinines, aspergillic acid, cyclopiazonic acid, parasiticolides, kojic acid, aspergillic acid, paspaline, paspalinine and emodin SB and is very similar to the eight Argentinean strains (Table 2).
Four isolates (CBS 117610-117612 and CBS 117615) produced aflatoxins $B_{1}, B_{2}, G_{1}$ and $G_{2}(100 \%)$, aspergillic acid $(33 \%)$, chrysogine $(67 \%)$, oryzaechlorin $(17 \%)$, parasiticolide $(50 \%)$, an extrolite with parasiticolide chromophore (50\%), extrolite NO2 (100\%) and extrolite EPIF $(100 \%)$. All strains had a floccose colony texture and 
Table 2. Production of mycotoxins and other extrolites by selected species in Aspergillus section Flavi based on HPLC-DAD analyses

Domesticated species, A. oryzae and A. sojae, and species with yellow conidia, Petromyces alliaceus and A. lanosus, are not included. A, Kojic acid; B, aflatoxin $\mathrm{B}_{1}$; $\mathrm{C}$, aflatoxin $\mathrm{G}_{1}$; D, cyclopiazonic acid; E, aspergillic acid; F, asperfuran; G, parasiticolides; $\mathrm{H}$, chrysogine; I, aflavarins; J, paspalinin and paspaline; $\mathrm{K}$, aflatrems and aflavinines; $\mathrm{L}$, nominine.

\begin{tabular}{|c|c|c|c|c|c|c|c|c|c|c|c|c|}
\hline Species & A & B & C & D & $\mathbf{E}$ & $\mathbf{F}$ & G & $\mathbf{H}$ & I & $\mathbf{J}$ & $\mathbf{K}$ & $\mathbf{L}$ \\
\hline A. arachidicola & + & + & + & - & + & - & + & + & - & - & - & - \\
\hline A. avenaceus & - & - & - & - & - & - & - & - & - & - & - & - \\
\hline A. bombycis & + & + & + & - & \pm & - & - & - & - & - & - & - \\
\hline A. caelatus & + & - & - & \pm & - & - & - & - & - & - & - & - \\
\hline A. flavus & + & \pm & - & \pm & + & \pm & - & - & - & \pm & - & - \\
\hline A. leporis & + & - & - & - & - & - & - & - & - & - & - & - \\
\hline A. minisclerotigenes & + & + & + & + & + & - & + & - & + & + & + & - \\
\hline A. nomius & + & + & + & - & + & - & - & - & - & - & - & + \\
\hline A. parasiticus & + & + & + & - & + & - & + & - & - & \pm & - & - \\
\hline A. parvisclerotigenus & + & + & + & + & + & - & - & - & + & + & + & - \\
\hline A. pseudotamarii & + & + & - & \pm & - & - & - & - & - & - & - & - \\
\hline A. tamarii & + & - & - & \pm & - & - & - & - & - & - & - & - \\
\hline
\end{tabular}

a conidium colour similar to that of $A$. flavus but, except for the production of chrysogine by most isolates, they exhibited extrolite profiles characteristic of A. parasiticus. Chrysogine production was also observed in A. cf. nomius NRRL 3353, a strain that had formerly been characterized as being an atypical A. flavus (Hesseltine et al., 1970). These strains had a conidial ornamentation between $A$. parasiticus and $A$. flavus, in agreement with isolates determined as 'otype' by Feibelman et al. (1998) and Kumeda et al. (2003).

\section{DISCUSSION}

The isolates representing two new taxa are related to either A. parasiticus or A. parvisclerotigenus. The isolates proposed here as Aspergillus arachidicola sp. nov. are not as dark green (Raper \& Fennell, 1965) as A. parasiticus. The conidiophores are regularly biseriate, but uniseriate conidial heads are also produced. However, conidium shape and ornamentation and other microscopical characteristics of $A$. arachidicola overlap with those of $A$. parasiticus. The production of aflatoxins $B$ and $G$ and lack of CPA production are similar in these two species, but the production of chrysogine and the negative results on AFPA of $A$. arachidicola are valuable characters for distinguishing these two species.

A. flavus is different from A arachidicola by its yellowishgreen colony colour (Raper \& Fennell, 1965) and the inability to produce type-G aflatoxins. Typical A. flavus isolates produce aflatoxin $\mathrm{B}_{1}, \mathrm{CPA}$ and aspergillic acid (Samson et al., 2004). Both species have roughened stipes, but $A$. flavus usually has longer stipes (more than $1000 \mu \mathrm{m}$ ), and also have smooth or finely roughened conidia.

Aspergillus minisclerotigenes sp. nov. is proposed as a new taxon for isolates with typical small sclerotia which came from peanut plants or peanut fields from Argentina, Australia, Nigeria and Texas. Some of these isolates have been described as A. flavus group II by Geiser et al. (1998, 2000). These isolates resemble A. parvisclerotigenus (CBS $121.62^{\mathrm{T}}$ ) on the basis of morphological characteristics and extrolite production, but differ by producing parasiticolide, while A. parvisclerotigenus produces the compounds A 30461 and speradine A, not detected in A. minisclerotigenes. Large amounts of parasiticol, sterigmatocystin and $O$ methylsterigmatocystin were also detected in A. parvisclerotigenus, but not in $A$. minisclerotigenes. On the other hand, A. minisclerotigenes was more effective than A. parvisclerotigenus in producing sclerotial metabolites (aflavinines, aflatrems, paspalinine, paspaline, aflavarins). However, all microsclerotial strains previously allocated to A. flavus appear to produce all these sclerotial indole metabolites (Tanaka et al., 1989). It has been shown that the biosynthesis of sclerotial metabolites and aflatoxin is regulated by the gene $v e A$, which is necessary for sclerotial formation in an isolate producing small sclerotia (Duran et al., 2007). A more detailed phenotypic study of more isolates representing A. parvisclerotigenus is necessary to determine whether there are more phenotypic differences between the two taxa that produce small sclerotia. However, our sequence data clearly show that the two microsclerotial species are genetically different.

\section{Taxonomy}

\section{Latin diagnosis of Aspergillus arachidicola Pildain, Frisvad \& Samson sp. nov. MB 505189}

Coloniae in agaro MEA dicto post 7 dies $25{ }^{\circ} \mathrm{C} 6-6.5 \mathrm{~cm}$ diametro, velutinae, olivaceae vel olivaceo-brunneae; reversum viridi-luteum. Conidiophora uniseriata, stipes hyalinus, 
asperulatus, (250-)400-600(-1000) × (6.5-)9-10 $\mu \mathrm{m}$; vesiculae globosae vel subglobosae, (23-)28-50 $\mu \mathrm{m}$ diametro; metulae 9.5-13.5 ×5-6.5 $\mu \mathrm{m}$; phialides 7-11 $\times 3-6.5 \mu \mathrm{m}$. Conidia globosa vel subglobosa, echinulata, viridula, (3.5-) 4.5-5(-6.5) $\mu \mathrm{m}$. Sclerotia absentia.

Typus siccus in herb. CBS 117610 et ex-typus vivus, isolatus Arachis glabrata, Corrientes provincia Argentina.

\section{Description of Aspergillus arachidicola Pildain, Frisvad \& Samson sp. nov. MB 505189}

Aspergillus arachidicola (a.ra.chi.di.co'la. N.L. n. arachidicola inhabitant of Arachis).

Colonies on YES, MEA, OA and CYA attain a diameter of 6-6.5 cm in 7 days at $25^{\circ} \mathrm{C}$; growing rapidly on CYA at $37{ }^{\circ} \mathrm{C}$, with a diameter of 6-7 cm (Fig. 2; a colour version
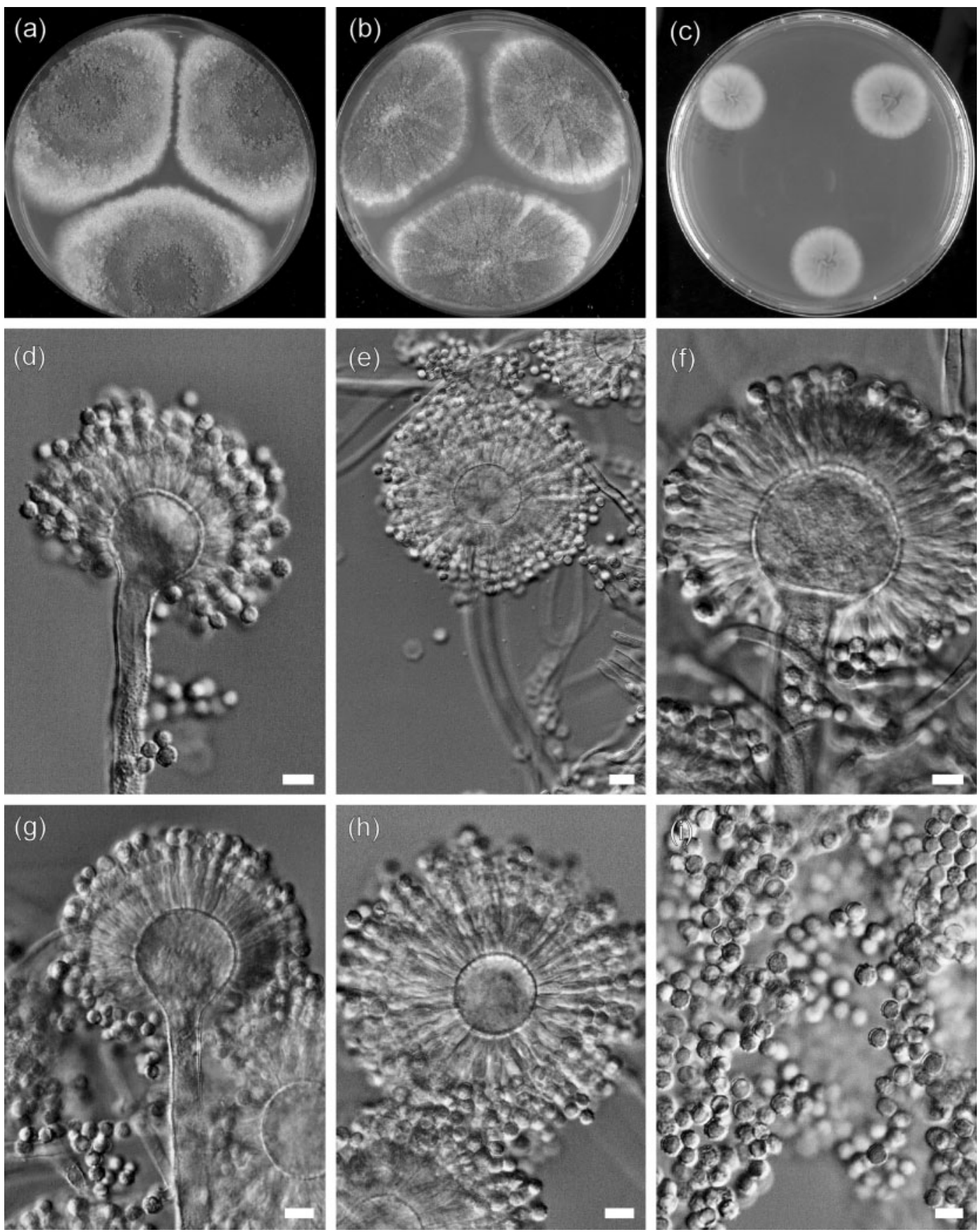

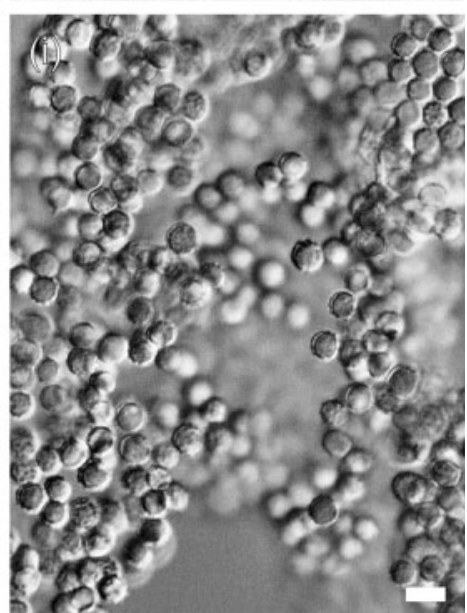

Fig. 2. Aspergillus arachidicola sp. nov. CBS $117610^{\top}$. (a-c) Colonies on CYA at $25^{\circ} \mathrm{C}$ (a), CYA at $37{ }^{\circ} \mathrm{C}$ (b) and AFPA (c) after 7 days. $(\mathrm{d}-\mathrm{h})$ Conidiophores; (i) conidia. Bars, $10 \mu \mathrm{m}$. A colour version of this figure is available as Supplementary Fig. S2. 
of this figure is available as Supplementary Fig. S2). Colony surface velvety with abundant conidial heads, olive to olive brown en masse (Kornerup \& Wanscher, 1978). Reverse greenish yellow without diffusible pigments. Sclerotia not observed. Conidial heads uniseriate or biseriate. Stipes hyaline, finely roughened, variable in length, mostly
(250-)400-600(-1000) $\mu \mathrm{m}$; diameter just below vesicles (6.5-)9-10 $\mu \mathrm{m}$. Vesicles globose to subglobose, (23-)28$50 \mu \mathrm{m}$ in diameter, fertile upper $75 \%$ of their surface; metulae 9.5-13.5 ×5-6.5 $\mu \mathrm{m}$; phialides 7-11 $\times 3-6.5 \mu \mathrm{m}$. Conidia globose to subglobose, echinulate, greenish, (3.5-) $4.5-5(-6.5) \mu \mathrm{m}$. Isolates grow well at 25,37 and $42{ }^{\circ} \mathrm{C}$.
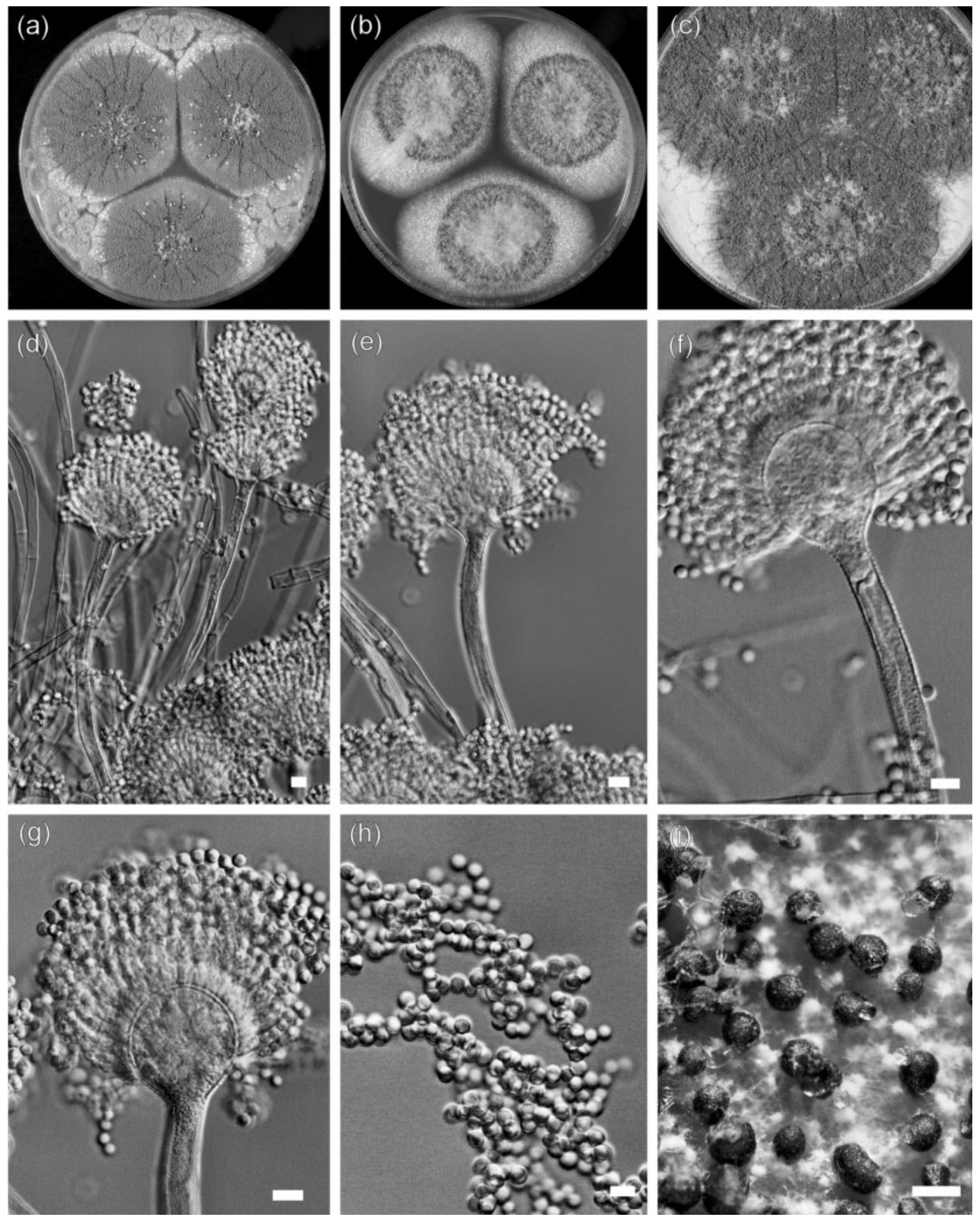

Fig. 3. Aspergillus minisclerotigenes sp. nov. CBS $117635^{\top}$. (a-c) Colonies on CYA at $25{ }^{\circ} \mathrm{C}(\mathrm{a})$, MEA (b) and YES agar (c) after 7 days. (d-g) Conidiophores; (h) conidia; (i) sclerotia. Bars, $10 \mu \mathrm{m}(\mathrm{a}-\mathrm{h})$ and $200 \mu \mathrm{m}$ (i). A colour version of this figure is available as Supplementary Fig. S3. 
Extrolites: strains of $A$. arachidicola produce kojic acid, aflatoxins $B_{1}, B_{2}, G_{1}$ and $G_{2}$ and parasiticolide, and some strains produce chrysogine.

The type strain, CBS $117610^{\mathrm{T}}=\mathrm{IBT} 25020^{\mathrm{T}}$, was isolated from an Arachis glabrata leaf, Corrientes province, Argentina.

\section{Latin diagnosis of Aspergillus minisclerotigenes Vaamonde, Frisvad \& Samson sp. nov. MB 505188}

Coloniae in agaro MEA dicto $6-7 \mathrm{~cm}$ diametro post 7 dies $25{ }^{\circ} \mathrm{C}$, velutinae vel floccosae, mycelium vegetatovum album et conidiophora sparsa et densum stratum sclerotiorum fuscorum formantes. Conidia aggregata dilute viridia vel griseo-viridia; reversum aurantiacum vel brunneum. Sclerotia copiosa, obscure brunnea vel atra, 150-300 $\mu \mathrm{m}$ diametro. Conidiophora biseriata, stipes hyalinus, asperatus, $1200-2000 \times 11-21 \mu \mathrm{m}$; vesiculae globosae vel subglobosae, 35-50 $\mu \mathrm{m}$ diametro, metulae 11-14 $\times 3-5 \mu \mathrm{m}$; phialideas 6 $10 \times 3-5 \mu \mathrm{m}$. Conidia subglobosa vel ellipsoidea, (2-)3-4(-6) $\mu \mathrm{m}$ diametro, dilute viridia, levia vel echinulata.

Typus siccus in herb. CBS 117635, et ex-typus vivus, isolatus Arachis hypogaea, Córdoba provincia Argentina.

\section{Description of Aspergillus minisclerotigenes Vaamonde, Frisvad \& Samson sp. nov. MB 505188}

Aspergillus minisclerotigenes (mi.ni.scle.ro.ti'ge.nes. N.L. part. adj. minisclerotigenes producing small sclerotia).

Colonies on YES, MEA, OA and CYA attain a diameter of 6$7 \mathrm{~cm}$ after 7 days at $25{ }^{\circ} \mathrm{C}$ and also on CYA at $37{ }^{\circ} \mathrm{C}$. Colony surface velvety and, on OA and MEA, colony surface floccose, consisting of white vegetative mycelium and sparse conidial heads and dense felt of dark sclerotia (Fig. 3; a colour version of this figure is available as Supplementary Fig. S3). Conidial structures light-greyish green en masse (Kornerup \& Wanscher, 1978). Colony reverse greyish orange to brownish orange on YES, yellowish brown to light brown on MEA and OA and brown on CYA. Exudate droplets are not observed. Sclerotia $150-300 \mu \mathrm{m}$ in diameter. Conidial heads normally biseriate, but uniseriate heads sometimes occur. Conidiophore stipes 1200-2000 × 11-21 $\mu \mathrm{m}$, hyaline, coarsely roughened. Vesicles globose to subglobose, 35$50 \mu \mathrm{m}$ in diameter. Metulae $11-14 \times 3-5 \mu \mathrm{m}$, phialides $6-$ $10 \times 3-5 \mu \mathrm{m}$. Conidia ellipsoidal, subglobose (2-)3-4(-6) $\mu \mathrm{m}$ diameter, pale green, smooth walled to echinulate. Isolates grow well at 25,37 and $42{ }^{\circ} \mathrm{C}$.

Extrolites: aspergillic acid, kojic acid, cyclopiazonic acid, aflatoxins $B_{1}, B_{2}, G_{1}$ and $G_{2}$, parasiticolides, paspaline and paspalinine, aflavarin, aflavinines and aflatrem. Aspergillic acid produced on AFPA.

The type strain CBS $117635^{\mathrm{T}}=\mathrm{IBT} 25032^{\mathrm{T}}$ (dried culture) was isolated from Arachis hypogaea, Córdoba province, Argentina.

\section{ACKNOWLEDGEMENTS}

We are indebted to D. Geiser (Pennsylvania State University, University Park, USA) and J. I. Pitt (CSIRO, North Ryde, Australia) for providing us with Aspergillus isolates for this study.

\section{REFERENCES}

Applegate, K. L. \& Chipley, J. R. (1973). Increased aflatoxin $G_{1}$ production by Aspergillus flavus via gamma irradiation. Mycologia 65, 1266-1273.

Austwick, P. K. C. \& Ayerst, G. (1963). Groundnut microflora and toxicity. Chem Ind 1963, 55-61.

Bayman, P. \& Cotty, P. J. (1993). Genetic diversity in Aspergillus flavus: association with aflatoxin production and morphology. Can $\mathrm{J}$ Bot 71, 23-31.

Bennett, J. W. \& Papa, K. E. (1988). The aflatoxigenic Aspergillus spp. Adv Plant Pathol 6, 263-280.

Chang, P.-K., Ehrlich, K. C. \& Hua, S.-S. T. (2006). Cladal relatedness among Aspergillus oryzae isolates and Aspergillus flavus $\mathrm{S}$ and L morphotype isolates. Int J Food Microbiol 108, 172-177.

Codner, R. C., Sargeant, K. \& Yeo, R. (1963). Production of aflatoxin by the culture of strains of Aspergillus flavus-oryzae on sterilized peanuts. Biotechnol Bioeng 5, 185-192.

Cole, R. A. \& Cox, R. H. (1981). Handbook of Toxic Fungal Metabolites. New York: Academic Press.

Cotty, P. J. (1989). Virulence and cultural characteristics of two Aspergillus flavus strains pathogenic on cotton. Phytopathology 79, 808-814.

Cotty, P. J. \& Cardwell, K. F. (1999). Divergence of West African and North American communities of Aspergillus section Flavi. Appl Environ Microbiol 65, 2264-2266.

Dorner, J. W., Cole, R. J. \& Diener, U. L. (1984). The relationship of Aspergillus flavus and Aspergillus parasiticus with reference to production of aflatoxins and cyclopiazonic acid. Mycopathologia 87, 13-15.

Duran, R. M., Cary, J. W. \& Calvo, A. M. (2007). Production of cyclopiazonic acid, aflatrem, and aflatoxin by Aspergillus flavus is regulated by $v e A$, a gene necessary for sclerotial formation. Appl Microbiol Biotechnol 73, 1158-1168.

Egel, D. S., Cotty, P. J. \& Elias, K. S. (1994). Relationships among isolates of Aspergillus sect. Flavi that vary in aflatoxin production. Phytopathology 84, 906-912.

Ehrlich, K. C., Chang, P.-K., Yu, J. \& Cotty, P. J. (2004). Aflatoxin biosynthesis cluster gene cypA is required for $\mathrm{G}$ aflatoxin formation. Appl Environ Microbiol 70, 6518-6524.

Feibelman, T. P., Cotty, P. J., Doster, M. A. \& Michailides, T. J. (1998). A morphologically distinct strain of Aspergillus nomius. Mycologia 90, 618-623.

Frisvad, J. C. \& Samson, R. A. (2004a). Emericella venezuelensis, a new species with stellate ascospores producing sterigmatocystin and aflatoxin $\mathrm{B}_{1}$. Syst Appl Microbiol 27, 672-680.

Frisvad, J. C. \& Samson, R. A. (2004b). Polyphasic taxonomy of Penicillium subgenus Penicillium. A guide to identification of food and air-borne terverticillate Penicillia and their mycotoxins. Stud Mycol 49, 1-174.

Frisvad, J. C. \& Thrane, U. (1993). Liquid column chromatography of mycotoxins. In Chromatography of Mycotoxins: Techniques and Applications, pp. 253-372. Edited by V. Betina. Amsterdam: Elsevier.

Frisvad, J. C., Houbraken, J. \& Samson, R. A. (1999). Aspergillus species and aflatoxin production: a reappraisal. In Food Microbiology 
and Food Safety into the Next Millennium, pp. 125-126. Edited by A. C. J. Tuijtelaars, R. A. Samson, F. M. Rombouts \& S. Notermans. Zeist: Foundation Food Micro '99.

Frisvad, J. C., Samson, R. A. \& Smedsgaard, J. (2004). Emericella astellata, a new producer of aflatoxin $\mathrm{B}_{1}, \mathrm{~B}_{2}$ and sterigmatocystin. Lett Appl Microbiol 38, 440-445.

Frisvad, J. C., Skouboe, P. \& Samson, R. A. (2005). Taxonomic comparison of three different groups of aflatoxin producers and a new efficient producer of aflatoxin $\mathrm{B}_{1}$, sterigmatocystin and 3-Omethylsterigmatocystin, Aspergillus rambellii sp. nov. Syst Appl Microbiol 28, 442-453.

Geiser, D. M., Pitt, J. I. \& Taylor, J. W. (1998). Cryptic speciation and recombination in the aflatoxin-producing fungus Aspergillus flavus. Proc Natl Acad Sci U S A 95, 388-393.

Geiser, D. M., Dorner, J. W., Horn, B. W. \& Taylor, J. W. (2000). The phylogenetics of mycotoxin and sclerotium production in Aspergillus flavus and Aspergillus oryzae. Fungal Genet Biol 31, 169-179.

Glass, N. L. \& Donaldson, G. C. (1995). Development of primer sets designed for use with the PCR to amplify conserved genes from filamentous ascomycetes. Appl Environ Microbiol 61, 1323-1330.

Hesseltine, C. W., Shotwell, O. L., Ellis, J. J. \& Stubblefield, R. D. (1966). Aflatoxin formation by Aspergillus flavus. Microbiol Mol Biol Rev 30, 795-805.

Hesseltine, C. W., Shotwell, O. L., Smith, M., Ellis, J. J., Vandegraft, E. \& Shannon, G. (1970). Production of various aflatoxins by strains of the Aspergillus flavus series. In Toxic Microorganisms: Mycotoxins, Botulism, pp. 202-210. Edited by M. Herzberg. Washington DC: UJNR Joint Panels on Toxic Micro-Organisms and the US Department of the Interior.

Hillis, D. M. \& Bull, J. J. (1993). An empirical test of bootstrapping as a method for assessing confidence in phylogenetic analysis. Syst Biol 42, 182-192.

Hong, S. B., Cho, H. S., Shin, H. D., Frisvad, J. C. \& Samson, R. A. (2006). Novel Neosartorya species isolated from soil in Korea. Int J Syst Evol Microbiol 56, 477-486.

Horn, B. W. (1997). Aspergillus caelatus, a new species in section Flavi. Mycotaxon 61, 185-191.

Houbraken, J., Due, M., Varga, J., Meijer, M., Frisvad, J. C. \& Samson, R. A. (2007). Polyphasic taxonomy of Aspergillus section Usti. Stud Mycol 59, 107-128.

Ito, Y., Peterson, S. W., Wicklow, D. T. \& Goto, T. (2001). Aspergillus pseudotamarii, a new aflatoxin producing species in Aspergillus section Flavi. Mycol Res 105, 233-239.

JECFA (1997). Evaluation of certain food additives and contaminants. Forty-sixth report of the Joint FAO/WHO Expert Committee on Food Additives 1996. WHO Technical Report Series 868. Geneva: World Health Organization.

Klich, M. A. \& Pitt, J. I. (1985). Differentiation of Aspergillus flavus from A. parasiticus and other closely related species. Trans Br Mycol Soc 91, 99-108.

Klich, M. A., Mullaney, E. J., Daly, C. B. \& Cary, J. W. (2000). Molecular and physiological aspects of aflatoxin and sterigmatocystin biosynthesis by Aspergillus tamarii and A. ochraceoroseus. Appl Microbiol Biotechnol 53, 605-609.

Kornerup, A. \& Wanscher, J. H. (1978). Methuen Handbook of Colour, 3rd edn. London: Eyre Methuen.

Kumar, S., Tamura, K. \& Nei, M. (2004). MEGA3: integrated software for molecular evolutionary genetics analysis and sequence alignment. Brief Bioinform 5, 150-163.

Kumeda, Y., Asao, T., Takahashi, H. \& Ichinoe, M. (2003). High prevalence of $B$ and $G$ aflatoxin-producing fungi in sugarcane field soil in Japan: heteroduplex panel analysis identifies a new genotype within Aspergillus section Flavi and Aspergillus nomius. FEMS Microbiol Ecol 45, 229-238.

Kurtzman, C. P., Horn, B. W. \& Hesseltine, C. W. (1987). Aspergillus nomius, a new aflatoxin-producing species related to Aspergillus flavus and Aspergillus parasiticus. Antonie van Leeuwenhoek 53, 147-158.

Murakami, H. (1971). Classification of the koji mold. J Gen Appl Microbiol 17, 281-309.

Murakami, H., Hayashi, K. \& Ushijima, S. (1982). Useful key characters separating three Aspergillus taxa: A. flavus, A. parasiticus and A. flavus. J Gen Appl Microbiol 28, 55-60.

Novas, M. V. \& Cabral, D. (2002). Association of mycotoxin and sclerotia production with compatibility groups in Aspergillus flavus from peanut in Argentina. Plant Dis 86, 215-219.

Peterson, S. W., Ito, Y., Horn, B. W. \& Goto, T. (2001). Aspergillus bombycis, a new aflatoxigenic species and genetic variation in its sibling species, A. nomius. Mycologia 93, 689-703.

Pildain, M. B., Vaamonde, G. \& Cabral, D. (2003). Compatibilidad vegetativa y diversidad genética en Aspergillus flavus de la provincia de Salta, Argentina. Bol Soc Argent Bot 38 (Suppl.), 275 (in Spanish).

Pildain, M. B., Vaamonde, G. \& Cabral, D. (2004). Analysis of population structure of Aspergillus flavus from peanut based on vegetative compatibility, geographic origin, mycotoxin and sclerotia production. Int J Food Microbiol 93, 31-40.

Pildain, M. B., Cabral, D. \& Vaamonde, G. (2005). Poblaciones de Aspergillus flavus en maní cultivado en diferentes zonas agroecológicas de la Argentina, caracterización morfológica y toxigénica. Rev Invest Agropec 34, 3-19 (in Spanish).

Pitt, J. l., Hocking, A. D. \& Glenn, D. R. (1983). An improved medium for detection of Aspergillus flavus and A. parasiticus. J Appl Bacteriol 54, 109-114.

Raper, K. B. \& Fennell, D. I. (1965). The Genus Aspergillus. Baltimore: Williams \& Wilkins.

Saito, M. \& Tsurota, O. (1993). A new variety of Aspergillus flavus from tropical soil in Thailand and its aflatoxin productivity. Proc Jpn Assoc Mycotoxicol 37, 31-36.

Samson, R. A., Hoekstra, E. S. \& Frisvad, J. C. (editors) (2004). Introduction to Food- and Airborne Fungi, 7th edn. Utrecht: Centraalbureau voor Schimmelcultures.

Samson, R. A., Noonim, P., Meijer, M., Houbraken, J., Frisvad, J. C. \& Varga, J. (2007a). Diagnostic tools to identify black aspergilli. Stud Mycol 59, 129-145.

Samson, R. A., Hong, S., Peterson, S. W., Frisvad, J. C. \& Varga, J. (2007b). Polyphasic taxonomy of Aspergillus section Fumigati and its teleomorph Neosartorya. Stud Mycol 59, 147-203.

Schroeder, H. W. (1966). Effect of corn steep liquor on mycelial growth and aflatoxin production in Aspergillus parasiticus. Appl Microbiol 14, 381-385.

Smedsgaard, J. (1997). Micro-scale extraction procedure for standardized screening of fungal metabolite production in cultures. J Chromatogr A 760, 264-270.

Swofford, D. L. (2000). PAUP ${ }^{*}$ 4.0: phylogenetic analysis using parsimony. Sunderland, MA: Sinauer Associates.

Tanaka, T., Hasegawa, A., Aoki, N., Yamamoto, S., Udagawa, S., Sekita, S., Harada, M., Nozawa, K. \& Kawai, K. (1989). Production of aflatrem and its related indoloditerpenes by microsclerotium-producing strains of Aspergillus flavus. Proc Jpn Assoc Mycotoxicol 30, 19-23.

Thompson, J. D., Higgins, D. G. \& Gibson, T. J. (1994). CLUSTAL W: improving the sensitivity of progressive multiple sequence alignment through sequence weighting, position-specific gap penalties and weight matrix choice. Nucleic Acids Res 22, 4673-4680. 
Vaamonde, G., Degrossi, C., Comerio, R. \& Fernandez Pinto, V. (1995).

Aspergillus flavus y A. parasiticus en maní cultivado en la provincia de Córdoba (Argentina): Características diferenciales y capacidad aflatoxicogénica. Bol Soc Argent Bot 30, 191-198 (in Spanish).
Varga, J., Due, M., Frisvad, J. C. \& Samson, R. A. (2007). Taxonomic revision of Aspergillus section Clavati based on molecular, morphological and physiological data. Stud Mycol 59, 89-106. 